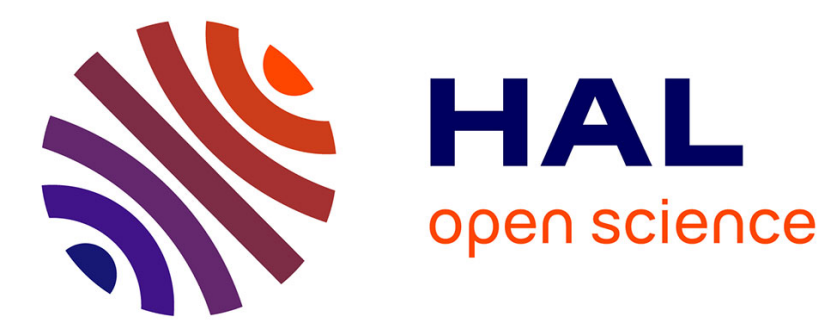

\title{
METALORGANIC PRECURSORS FOR SEMICONDUCTORS REQUIREMENTS AND RECENT DEVELOPMENTS
}

A.C . Jones

\section{- To cite this version:}

A.C . Jones. METALORGANIC PRECURSORS FOR SEMICONDUCTORS REQUIREMENTS AND RECENT DEVELOPMENTS. Journal de Physique IV Proceedings, 1991, 02 (C2), pp.C2-253C2-261. 10.1051/jp4:1991231 . jpa-00249820

\section{HAL Id: jpa-00249820 https://hal.science/jpa-00249820}

Submitted on 1 Jan 1991

HAL is a multi-disciplinary open access archive for the deposit and dissemination of scientific research documents, whether they are published or not. The documents may come from teaching and research institutions in France or abroad, or from public or private research centers.
L'archive ouverte pluridisciplinaire HAL, est destinée au dépôt et à la diffusion de documents scientifiques de niveau recherche, publiés ou non, émanant des établissements d'enseignement et de recherche français ou étrangers, des laboratoires publics ou privés. 
Colloque C2, suppl. au Journal de Physique II, Vol. 1, septembre 1991

\title{
METALORGANIC PRECURSORS FOR SEMICONDUCTORS REQUIREMENTS AND RECENT
} DEVELOPMENTS

\author{
A.C. JONES \\ Epichem Limited, Power Road, Bromborough, Wirral, \\ GB-Mersesydide L62 3QF, Great-Britain
}

\section{Abstract}

Recent advances in the growth of III-V and II-VI semiconductor materials by MOVPE have been greatly facilitated by the development of new metalorganic precursors. The use of trimethylamine alane $\left(\mathrm{AlH}_{3}\left(\mathrm{NMe}_{3}\right)\right)$ has allowed the growth of AlGaAs with greatly lowered carbon and oxygen levels, whilst adducts such as $\mathrm{Me}_{2} \mathrm{ZnNEt}_{3}$ have served to eliminate a formerly severe prereaction during growth of $\mathrm{znse}$ and $\mathrm{zns}$. A number of these recent developments are critically reviewed and possible growth mechanisms are discussed.

\section{INTRODUCTION}

It is now over twenty years since Manasevit showed that metalorganic compounds could be used as volatile sources of the group III element for the growth of III-V semiconductors by metalorganic vapour phase epitaxy (MOVPE) [1]. He then demonstrated the versatility of the technique by using MOVPE to grow a range of III-V, and II-VI semiconductor materials [2].

A fundamental requirement of the metalorganic precursor used in MOVPE is one of high purity. It is well established that the electrical and optical properties of the semiconductor layers are critically dependent on trace impurities in the metalorganic compound [3]. In this respect, much progress has been made.

The application of novel synthesis and purification techniques such as adduct purification [4-6], together with advances in analysis [3] have allowed the preparation of metalorganic precursors with a total metal impurity content of <1ppm. This, in turn, has facilitated the routine growth of high purity III-V and II-VI semiconductors by MOVPE.

The metalorganic precursors must also possess convenient physical properties (e.g. vapour pressure), together with suitable decomposition characteristics, which lead to a clean pyrolysis with minimal side reactions during epitaxial layer growth.

Although many of the metalorganic precursors currently used are those proposed by Manasevit, in certain areas of III-V and II-VI MOVPE the use of conventional precursors is problematic. Therefore, alternatives are required. In this paper, the development of some of these new precursors is critically reviewed and possible growth mechanisms are discussed. 


\section{GROWTH OF AIGAAS USING ALTERNATIVE ALUMINIUM PRECURSORS}

The growth of AlGaAs by MOVPE has traditionally been carried out using trimethylaluminium ( $\mathrm{Me}_{3} \mathrm{Al}$ ) in combination with trimethylgallium $\left(\mathrm{Me}_{3} \mathrm{Ga}\right)$ and arsine $\left(\mathrm{AsH}_{3}\right)$ [7]. However, the use of $\mathrm{Me}_{3} \mathrm{Al}$ leads to AlGaAs layers which are significantly contaminated with carbon [8]. The low temperature photoluminescence (PL) spectrum of these layers, is shown in figure 1.

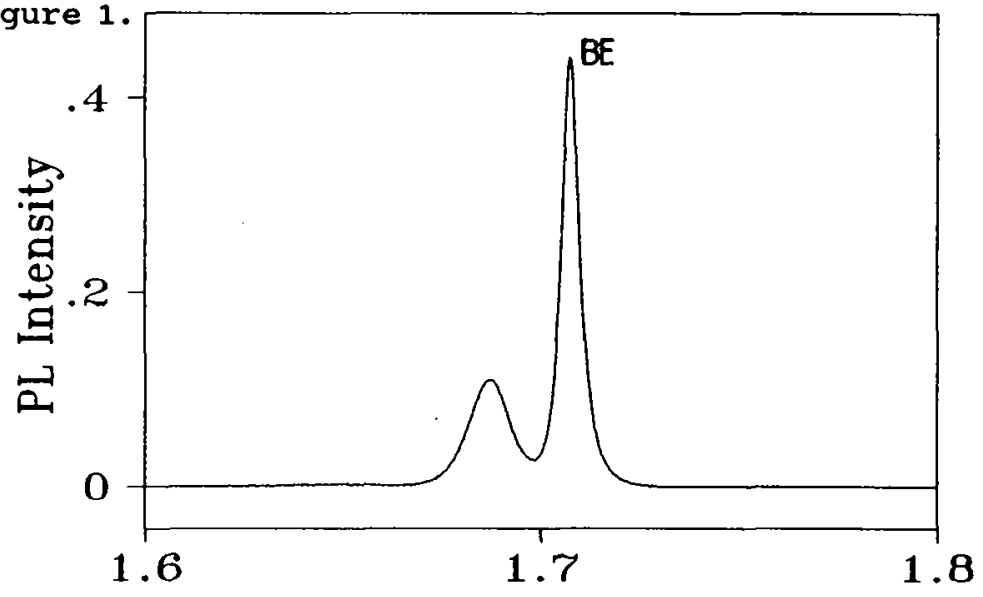

\section{Electron Volts}

Figure 1. $10 \mathrm{~K}$ PL spectrum for $\mathrm{Al}_{0.23} \mathrm{Ga}_{0.77^{A s}}$ grown using $\mathrm{Me}_{3} \mathrm{Al}$ and $\mathrm{Me}_{3} \mathrm{Ga}$

The PL spectrum typically shows a band edge (BE) component associated with bound excitonic emission, together with a secondary peak at approximately $20 \mathrm{meV}$ lower energy. This can be assigned to a free to bound (F-B) transition associated with carbon contamination [8]. The inclusion of carbon leads to AlgaAs layers which are typically p-type at $x>0.3$.

It has been proposed [8] that this contamination arises due to the incomplete elimination of methyl groups from $\mathrm{Me}_{3} \mathrm{Al}$ during $\mathrm{AlGaAs}$ growth. This proposal is supported by work in our laboratory in which AlGaAs has been grown using $\mathrm{Me}_{3} \mathrm{AlNMe}_{3}\left[{ }^{9}\right],\left(\mathrm{Me}_{2} \mathrm{AlNMe}_{2}\right)_{2}[9]$, tert-Butyl-AlMe $[10],\left(\mathrm{Me}_{2} \mathrm{AlH}\right)_{2}[11]$ and $\mathrm{Me}_{2} \mathrm{AlH}\left(\mathrm{NMe}_{3}\right)^{2}$ [11]. None of these alternatives showed any advantage over $\mathrm{Me}_{3} \mathrm{Al}$ in lowering carbon contamination. This strongly suggests that, for all aforementioned precursors, a similar carbon bearing species $\left(\mathrm{AlMe}_{2}\right.$ or AlMe) is present at or near the substrate during epitaxial layer growth.

It is therefore necessary to investigate alternative aluminium precursors which do not contain the $\left[\mathrm{Al}-\mathrm{CH}_{3}\right]$ moiety. Although triethylaluminium $\left(\mathrm{Et}_{3} \mathrm{Al}\right)$ [12] and trimethylamine-diethylalane $\left(E t_{2} \mathrm{AlH}\left(\mathrm{NMe}_{3}\right)\right)$ [11] have been the subject of preliminary studies, both precursors have low vapour pressures of $0.04 \mathrm{~mm}\left(27^{\circ} \mathrm{C}\right)$ and $0.4 \mathrm{~mm}$ $\left(20^{\circ} \mathrm{C}\right)$ respectively. This Iimits their wide application in MOVPE.

However, trimethylamine alane $\left(\mathrm{AlH}_{3}\left(\mathrm{NMe}_{3}\right)\right)$ has considerably more potential. This monomeric adduct precursor contains no direct aluminium-carbon bonds and has an adequate vapour pressure of 
$1.8 \mathrm{~mm}$ a $25^{\circ} \mathrm{C}$ for MOVPE applications. Furthermore, $\mathrm{AlH}_{3}\left(\mathrm{NMe}_{3}\right)$ is not expected to form volatile oxides and has been shown to lower both carbon and oxygen contamination in AlGaAs grown by the vacuum epitaxy technique, MOMBE [13]. We have subsequently used $\mathrm{AlH}_{3}\left(\mathrm{NMe}_{3}\right)$ in combination with $\mathrm{Me}_{3} \mathrm{Ga}$ and arsine to grow high quality AlGaAs by MOVPE at atmospheric pressure [14] and reduced pressure [15]. However, despite the use of an aluminium hydride precursor, low temperature PL data showed that carbon was still a significant contaminant in the AlGaAs layers.

Although the exact mechanism for carbon incorporation has not been established, these results indicate that the Me ${ }_{3}$ Ga precursor is now acting as the source of carbon. Although GaAs may be grown with no significant carbon contamination using $\mathrm{Me}_{3} \mathrm{Ga}$ and $\mathrm{AsH}_{3}$ [7], the presence of aluminium, both in the gas phase and at the substrate surface radically alters the growth mechanism.

The pyrolysis of $\mathrm{Me}_{3} \mathrm{Ga}$ at or near the substrate surface will generate methyl radicals. The vast majority are removed ('gettered') by active hydrogen generated from the pyrolysis of $\mathrm{AsH}_{3}$ or $\mathrm{AlH}_{3}\left(\mathrm{NMe}_{3}\right)$. However, a small proportion become strongly bound to a deposited aluminium atom, see figure 2, leading to subsequent carbon incorporation via sequential hydrogen abstraction.
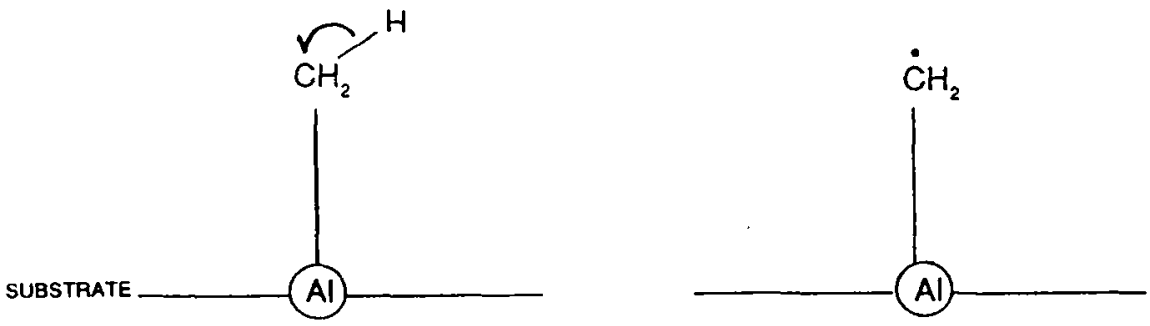

Figure 2. Proposed mechanism for carbon incorporation by adsorption of methyl radicals on an AlGaAs growth surface.

Gas phase interactions between $\mathrm{AlH}_{3}\left(\mathrm{NMe}_{3}\right)$ and $\mathrm{Me}_{3} \mathrm{Ga}$ are also likely to play a role in carbon incorporation in the grown layers. This is certainly the case for AlGaAs grown at atmospheric pressure in which considerable darkening of the reactor was observed, and the layers were found to be non-uniform showing a marked increase in aluminium content in the downstream direction [14]. Recent infrared studies [16] have rationalized this effect as due to a gas phase reaction between $\mathrm{AlH}_{3}\left(\mathrm{NMe}_{3}\right)$ and $\mathrm{Me}_{3} \mathrm{Ga}$ which produces unstable species such as $\mathrm{Me}_{2} \mathrm{GaH}$ and $\mathrm{MeGaH}_{2}$. This leads to the premature deposition of GaAs upstream and at the reactor inlet. Furthermore, the infrared data indicate that $\mathrm{Al}-\mathrm{CH}_{3}$ species, precursors to carbon incorporation, are formed via a gas phase transalkylation.

In the case of low pressure growth [15], there was little evidence of pre-reaction between $\mathrm{AlH}_{3}\left(\mathrm{NMe}_{3}\right)$ and $\mathrm{Me} \mathrm{G}_{3} \mathrm{Ga}$, due to the greatly reduced mixing or residence time of the reagents in the reactor cell. The continued presence of carbon in the AlGaAs layers strongly suggests that, for low pressure MOVPE, a surface mechanism of the type shown in figure 2 is dominant. 
In order to exclude carbon from MOVPE - grown AlGaAs it is therefore necessary to investigate precusor combinations in which the methyl radical is not available for participation in the growth process.

Thus, we have recently demonstrated the successful growth of AlGaAs by low pressure MOVPE using $\mathrm{AlH}_{3}\left(\mathrm{NMe}_{3}\right)$ in combination with triethylgalifum $\left(\mathrm{Et}_{3} \mathrm{Ga}\right)$ and $\mathrm{AsH}_{3}[17]$. The low temperature $\mathrm{PL}$ spectrum of an $\mathrm{Al}_{0} .14 \mathrm{Ga}, 36^{\mathrm{As}}$ layer, shown in figure 3 , exhibits only a single peak. (FWHM 4 mev) attributable to bound excitonic emission. The F-B emission peak is virtually absent, indicating that carbon is no longer a significant contaminant in the AlGaAs layers. This is also reflected in the electrical properties of these layers, whigh were n-type with a residual carrier concentration $(n)=5 \times$ $10^{15} \mathrm{~cm}^{-3}[17]$.

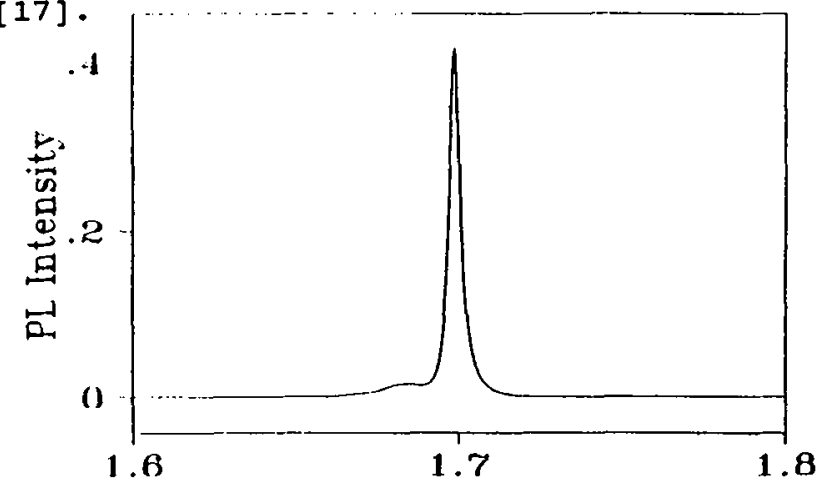

Electron Volts

Figure 3 . $10 \mathrm{~K}$ PL spectrum $\mathrm{Al}_{0.14} \mathrm{Ga}_{0.86^{\mathrm{As}}}$ grown using $\mathrm{AlH}_{3}\left(\mathrm{NMe}_{3}\right)$ and $\mathrm{Et}_{3} \mathrm{Ga}$

These results are entirely consistent with our contention that the trialkylgallium molecule acts as a source of alkyl radicals, which are supplied to the substrate during AlGaAs growth.

During growth using $\mathrm{Et}_{3} \mathrm{Ga}$, ethyl radicals arrive at the growth surface, see figure 4. Although the possibility still exists for adsorption to a surface aluminium atom, the ethyl radical is able to undergo $B$-hydride elimination. This allows the facile removal of stable carbon-containing fragments (i.e. ethylene) from the growth surface, consequently carbon incorporation is greatly lowered.

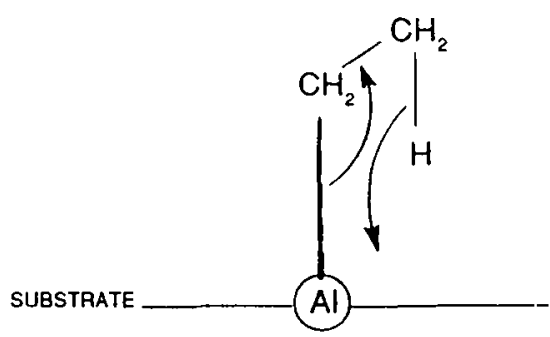

Figure 4. Proposed mechanism for removal of ethyl radicals from an

AlGaAs growth surface. 
The new aluminium precursor, $\mathrm{AlH}_{3}\left(\mathrm{NMe}_{3}\right)$ therefore represents a marked improvement over the conventional $\mathrm{Me}_{3} \mathrm{Al}$ precursor in greatly lowering carbon contamination in AlGaAs. Furthermore, preliminary results [18] indicate that oxygen contamination is also significantly reduced. These advantages, together with its acceptable physical properites (adequate vapour pressure) strongly suggest that $\mathrm{AlH}_{3}\left(\mathrm{NMe}_{3}\right)$ will have widespread application in the MOVPE growth of high purity AlGaAs.

\section{PRECURSORS FOR WIDE-GAP II-VI SEMICONDUCTORS}

\subsection{Precursors for zinc-based chalcogenides}

The growth of zinc selenide (znse) and zinc sulphide (zns) by MovPE was developed initially using diethylzinc ( $\mathrm{Et}_{2} \mathrm{Zn}$ ) [19] or dimethylzinc $\left(\mathrm{Me}_{2} \mathrm{Zn}\right)$ [20] in combination with either hydrogen selenide $\left(\mathrm{H}_{2} \mathrm{e}\right)$ or hydrogen sulphide $\left(\mathrm{H}_{2} \mathrm{~S}\right)$. However these precursor combinations lead to a serious problem of unwanted premature reaction which seriously limits the compositional uniformity of the II-VI epitaxial layers. It is therefore necessary to investigate alternative reactant species.

The aforementioned premature reaction may be attributed to the facile elimination of alkyl groups from the dialkylainc precursor in the presence of acidic hydrogen from $\mathrm{H}_{2} \mathrm{Se}$ or $\mathrm{H}_{2} \mathrm{~S}$. Therefore, a number of workers have investigated alternative group VI sources which do not contain acidic hydrogen. These include dialkyl selenides [21], dialkyl sulphides [22] and sulphur and selenium heterocycles [23] .

Unfortunately, although the premature reaction is eliminated, this approach invokes the penalty of higher than desirable deposition temperatures $\left(>400^{\circ} \mathrm{C}\right)$. This can lead to an increased concentration of impurities together with an increased occurence of native defect-impuritiy complexes [24].

In our laboratory we have adopted a different approach, in which the group II precursor is modified to reduce its susceptibility to premature reaction [25]. We have investigated a range of adducts between $\mathrm{Me}_{2} \mathrm{Zn}$ and a variety of oxygen and nitrogen donor ligands such as 1,4-dioxan [26], 1,4 thioxan [26], triethylamine $[27,28]$ and triazine [28].

The most effective adduct is dimethylzinc-triethylamine, $\mathrm{Me}_{2} \mathrm{ZnNEt}_{3}$, which has been shown to eliminate the prereaction with $\mathrm{H}_{2} \mathrm{Se}$ and $\mathrm{H}_{2} \mathrm{~S}$, whilst still retaining the advantage of $\mathrm{ZnS}_{\mathrm{x}} \mathrm{Se}_{1-\mathrm{x}}$ growth at lower temperature $\left(250-350^{\circ} \mathrm{C}\right)[27]$.

$\mathrm{Me}_{2} \mathrm{ZnNEt}_{3}$ possesses further advantages over $\mathrm{Me}_{2} \mathrm{Zn}$ in that it is more readily purified and is more convenient in use.

For instance, $\mathrm{Me}_{2} \mathrm{Zn}$ is invariably contaminated with traces of alkyl halide (RX) used in its synthesis. In subsequent II-VI layer growth, incorporation of halide leads to low quality znse with high residual n-type backgrounds. In the $\mathrm{Me}_{2} \mathrm{ZnNEt}_{3}$ adduct however, the presence of $\mathrm{NEt}_{3}$ effects the precipitation of any trace $\mathrm{RX}$ in the form of an involatile tetralkylammonium halide complex $\left[\mathrm{R}_{4} \mathrm{~N}^{+} \mathrm{X}^{-}\right]$. Redistillation of $\mathrm{Me}_{2} \mathrm{ZnNEt}_{3}$ then yields a halide-free precursor [28].

In addition, the $\mathrm{Me}_{2} \mathrm{ZnNEt}_{3}$ adduct has a covenient vapour pressure of $17 \mathrm{~mm}$ a $21^{\circ} \mathrm{C}$ for MOVPE applications. This permits the use of more convenient source temperatures and carrier gas flow rates than is the case for the more volatile $\mathrm{Me}_{2} \mathrm{Zn}$ (vap. $\mathrm{P}=300 \mathrm{~mm}$ e $20^{\circ} \mathrm{C}$ ). 
$\mathrm{Me}_{2}$ ZnNEt $_{3}$ therefore fulfills many of the criteria for an ideal MOVPE precursor and has allowed the reproducible growth of high quality znse with low residual carrier concentrations ( $\mathrm{n}<10^{15} \mathrm{~cm}^{-3}$ ) and high electron mobilities $\left(u_{77 \mathrm{~K}}-8,000 \mathrm{~cm}^{2} \mathrm{v}^{-1} \mathrm{~s}^{-1}\right)[28]$.

\subsection{Precursors for cadmium-based chalcogenides}

The problem of premature reaction is also severe in the growth of cadmium selendide (CdSe) and cadmium sulphide (CdS) using dimethylcadmium ( $\mathrm{Me}_{2} \mathrm{Cd}$ ) and $\mathrm{H}_{2} \mathrm{Se}$ or $\mathrm{H}_{2} \mathrm{~S}$. We have thus attempted to extend the use of group II alkyl adducts to the growth of these alloys.

However, although cds and cdse layers have been grown using $\mathrm{Me}_{2} \mathrm{Cd}-(1,4-d i o x a n)$ [29] and $\mathrm{Me}_{2} \mathrm{Cd}$ (tetrahydrothiophene) 2 [30], neither of these precursors eliminated prereaction with the group vI hydride. Therefore in an effort to rationalize this observed difference between alkylzinc - and alkyl cadmium - adducts, and to perhaps find a more general method for the control of prereaction, new precursor combinations have been investigated as described below.

\section{IN-SITU CONTROL OF PREREACTION DURING II-VI ALLOY GROWTH}

In the prevention of prereaction during the growth of Znse, the presence of nitrogen donor ligands is an important parameter. This is further emphasised by our recent studies [31] which have shown that the use of pyridine $\left(\mathrm{C}_{5} \mathrm{H}_{5} \mathrm{~N}\right)$, when introduced as an additive in the gas phase, eliminates the prereaction between $\mathrm{Me}_{2} \mathrm{Zn}$ and $\mathrm{H}_{2} \mathrm{Se}$.

Concommitant with the elimination of prereaction, the addition of $\mathrm{C}_{5} \mathrm{H}_{5} \mathrm{~N}$, even at very low concentrations, led to a marked increase in the growth rate of $\mathrm{znse}$, figure 5 .

The Znse layers grown in the presence of $\mathrm{C}_{5} \mathrm{H}_{5} \mathrm{~N}$ showed improved structural quality and had excellent electrical and optical properties [31].

In contrast, the addition of $\mathrm{C}_{5} \mathrm{H}_{5} \mathrm{~N}$ vapour had no effect on the growth rate of CdSe using $\mathrm{Me}_{2} \mathrm{Cd}$ and $\mathrm{H}_{2} \mathrm{Se}$ [31]. However, the presence of $\mathrm{C}_{5} \mathrm{H}_{5} \mathrm{~N}$ did lead to a change in the nature of the cell wall deposit, from a loosely consolidated black deposit to a red deposit with higher mechanical stability. This resulted in a considerable reduction in debris on the substrate surface leading to improved layer uniformity [31].

The precise mechanism by which nitrogen donors prevent prereaction during the growth of znse remains non-proven. Previously it had been assumed [27] that the inhibition of prereaction was due to the existence of relatively strong adducts, such as $\mathrm{Me}_{2} \mathrm{ZnNEt}_{3}$, in the gas phase which prevented premature interaction between $\mathrm{Me}_{2} \mathrm{Zn}$ and $\mathrm{H}_{2} \mathrm{Se}$. However, this adduct blocking mechanism is apparently precluded by recent infrared studies on such adducts which indicate that they are essentially dissociated in the gas phase, even at room temperature [32]. Further evidence against simple adduct blocking is provided by the growth rate data, figure 5, which shows that the prereaction is significantly inhibited at $\mathrm{C}_{5} \mathrm{H}_{5} \mathrm{~N}: \mathrm{Me}_{2} \mathrm{Zn}$ ratios as low as $0.05: 1$. This is much lower than the 1:1 ratio which might be predicted for effective adduct blocking. 


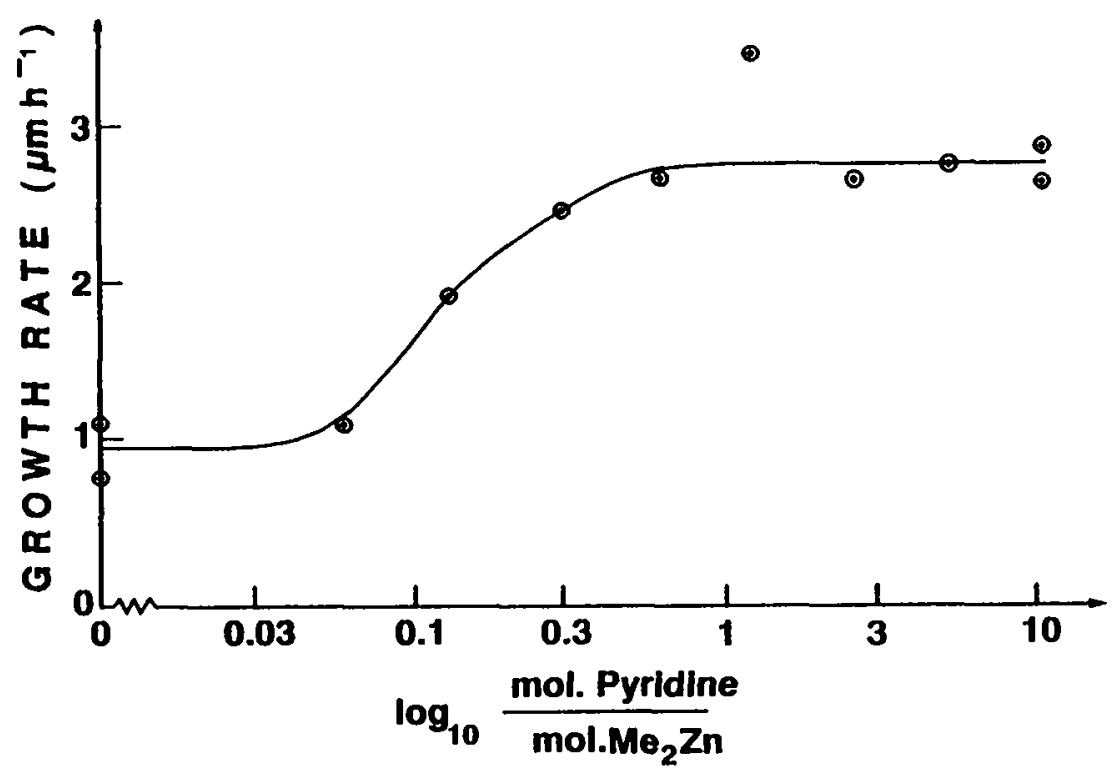

Figure 5. Effect of pyridine on growth rate of $\mathrm{znSe}$.

Therefore, we have proposed an alternative mechanism, [31] which involves the stabilization, by nitrogen donor molecules such as $\mathrm{NEt}_{3}$ and $\mathrm{C}_{5} \mathrm{H}_{5} \mathrm{~N}$, of highly reactive radical intermediates which may induce $a$ chain reaction. These reactive radicals may be generated in the cold zone of the reactor as follows:-

$\mathrm{Me}_{2} \mathrm{Zn}+\mathrm{H}_{2} \mathrm{Se} \longrightarrow(\mathrm{MeZn})+($ HSe $) \cdot+\mathrm{CH}_{4}$

A chain reaction then ensues which terminates thus:

$(\mathrm{MeZn}) \cdot+(\mathrm{HSe}) \cdot \longrightarrow \mathrm{ZnSe}+\mathrm{CH}_{4}$

In the absence of a stronger electron donor, the electrophilic radical $(\mathrm{Mezn})^{-}$is likely to instantly react with the chalcogen containing species $\mathrm{H}_{2} \mathrm{Se}$ or (HSe) leading to premature deposition of $\mathrm{znSe}$. However, in the case of growth with adducts, or when $\mathrm{C}_{5} \mathrm{H}_{5} \mathrm{~N}$ is present, the vapour contains a competing Lewis base which is a stronger donor toward (MeZn) than the chalcogen species. The nitrogen donor ligand is thus likely to complex with the metal-containing radicals and thus allow their transport to the substrate without further reaction.

The failure of $\mathrm{C}_{5} \mathrm{H}_{5} \mathrm{~N}$ to eliminate prereaction during the growth of CdSe may now be rationalized in terms of the 'soft' class B acceptor character of cadmium, which forms complexes more readily with selenium donors than with nitrogen donors. In this case, $\mathrm{H}_{2} \mathrm{Se}$ or (HSe) will be the strongest donors in the vapour phase and premature reaction with $\mathrm{Me}_{2} \mathrm{Cd}$ or (MeCd) will still occur. One possible solution is to add strong competing sulphur or selenium donors, such as thiophene $\left(\mathrm{C}_{4} \mathrm{H}_{4} \mathrm{~S}\right)$, selenophene $\left(\mathrm{C}_{4} \mathrm{H}_{4} \mathrm{Se}\right)$ or alkylsulphides and alkylselenides to the gas phase. This is now under investigation in our laboratory.

The in-situ modification of gas phase chemistry by the introduction of donor molecules, such as $\mathrm{C}_{5} \mathrm{H}_{5} \mathrm{~N}$, is an important new line of investigation for the chemist. Such modification may permit the use of precursors with the most convenient physical properities whilst still reducing unwanted side reactions and allowing the optimization of epitaxial layer growth. 


\section{ACKNOWLEDGEMENTS}

I would like to acknowledge the assistance of a number of U.K. centres for carrying out layer growth. In particular, I am grateful to Professor B. Cockayne and Dr. P. J. Wright (RSRE, Malvern), Dr. J. S. Roberts (Sheffield University) and Dr. J. I. Davies (Epitaxial Products International Ltd). I am also indebted to

Dr. P O'Brien (Queen Mary \& Westfield college, London) for discussion concerning II-VI reaction mechanisms.

\section{REFERENCES}

1. MANASEVIT H. M, Appl. Phys Lett, 12 (1968) 156.

2. MANASEVIT H. M, J. Crystal Growth, 55 (1981) 1.

3. JONES A. C, WALES G, WRIGHT P.J. and OLIVER P. E, chemtronics, 2 (1987) 83.

4. JONES A. C, COLE-HAMILTON D. J, HOLLIDAY A. K and AHMAD M. M, J. Chem Soc (Dalton) (1983) 1047 .

5. MOORE A. H, SCOTT M. D, DAVIES J. I, BRADLEY D. C, FAKTOR M. M, and CHUDZYNSKA H, J, Crystal Growth, 77 (1986) 19.

6. JONES A. C, Chemtronics, 4 (1989) 15.

7. Proc. 4th Intern. Conf. on MOVPE, Hakone, 1988, Eds. WATANABE N, NAKANISI $N$, and DAPKUS P.D, J. Crystal Growth 93 (1988) and refrences therein

8. KUECH T.F, VEUHOFF E, KUAN T.S, DELINE $V$, and POTEMSKI $R$, J. Crystal Growth, 77 (1986) 257.

9. JONES A. C, ROBERTS J.S, WRIGHT P.J, OLIVER P.E, and COCKAYNE B, Chemtronics, 3 (1988) 152 .

10. JONES A. C, JACOBS P. R, RUSHWORTH S. A, ROBERTS, J. S, BUTTON C. 'C, WRIGHT P.' J, OLIVER P. E' and COCKAYNE B, J. Crystal Growth 96 (1989) 789.

11. JONES A. C, WRIGHT P. J, OLIVER P. E, COCKAYNE B and ROBERTS J. S, J. Crystal Growth, 100 (1990) 395.

12. KOBAYASHI N, and MAKIMOTO T, Japan J. Appl. Phys, 24 (1985) L824

13. ABERNATHY C. R, JORDAN A. S, PEARTON S. J, HOBSON W. A, BOHLING D. A and MUHR G. T, Appl. Phys Lett, 56 (1990) 2654.

14. ROBERTS, J. S, BUTTON C. C, DAVID J. P. R, JONES A. C, and RUSHWORTH S. A, J. Crystal Growth, 104 (1990) 857 .

15. JONES A. C, RUSHWORTH S. A, BOHLING D. A. and MUHR G. T, J. Crystal Growth, 106 (1990) 246

16. GRADY A. S, MARKWELL R, RUSSELL D. $K$ and JONES A. $C$, J. Crystal Growth, 106 (1990) 239.

17. JONES A. C and RUSHWORTH S. A, J. Crystal Growth, 106 (1990) 253. 
18. ROBERTS J. S, (University of Sheffield) Personal Communication, 1991 .

19. BLANCONNIER P, HOGREL J. F, JEAN LOUIS A.M, and SERMAGE B, J Appl. Phys. 52 (1981) 6895.

20. WRIGHT P. J. and COCKAYNE B, J. Crystal Growth, 59 (1982) 148 .

21. MITSUHASHI H, MITSUISHI I and KUKIMOTO H, J. Appl. Phys. 24 (1985) 1864.

22. YOKUGAWA $T$, OGURA $M$ and KAJIWAR $T$, Appl. Phys. Lett, 49 (1986) 1702 .

23. WRIGHT P. J, GRIFFITHS R. J. M, and COCKAYNE B, J. Crystal Growth, 66 (1984) 26 .

24. COCKAYNE B, WRIGHT P. J, SKOLNICK M. S, PITT A. D, WILLIAMS J. 0 , and NG. T. L. J. Crystal Growth, 72 (1985) 17.

25. WRIGHT P. J, COCKAYNE B, WILLIAMS A. J, JONES A. $C$, and ORRELL E. D, J. Crystal Growrth, 84 (1987) 552.

26. COCKAYNE B, WRIGHT P. J, ARMSTRONG A. J, JONES A. C and ORRELL E. D. J. Crystal Growth, 91 (1988) 57.

27. WRIGHT P. J, PARBROOK P. J, COCKAYNE B, JONES A. C, ORRELI E. D, O'DONNELL K. P. and HENDERSON B, J. Crystal Growth, 94 (1989) 441.

28. WRIGHT P. J, COCKAYNE B, PARBROOK P. J, JONES A. C, O'BRIEN P, and WALSH J. R, J. Crystal Growth, 104 (1990) 601.

29. WRIGHT P. J, COCKAYNE B, JONES A. C, ORRELL E. D, O'BRIEN P, and KHAN O. F. Z, J. Crystal Growth, 94 (1989) 97.

30. JONES A. C, RUSHWORTH S. A, WRIGHT P. J, COCKAYNE B, O'BRIEN P, and WALSH J. R, J. Crystal Growth, 97 (1989) 537.

31. WRIGHT P. J, COCKAYNE B, PARBROOK P. J, OLIVER P. E, and JONES A. C, J. Crystal Growth, 108 (1991) 525.

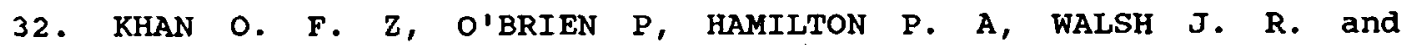
JONES A. C, Chemtronics, 4 (1989) 244. 